\title{
Effects of milking three times in 2 days for 3 weeks in early lactation or in the declining phase on milk production in primiparous and multiparous dairy cows
}

\author{
B Rémond*, MP Boit \\ Laboratoire adaptation des herbivores aux milieux, Inra-Theix, \\ 63122 Saint-Genès-Champanelle, France
}

(Received 18 September 1996; accepted 11 February 1997)

\begin{abstract}
Summary - Fifty-two Holstein cows (26 primiparous) were assigned at calving to two milking frequencies: either twice daily ( $6 \mathrm{~h}$ and $17 \mathrm{~h}$; control) or three times $/ 2$ days $(6 \mathrm{~h}, 20 \mathrm{~h}$ and $14 \mathrm{~h}$ of the following day) during the first 3 weeks of lactation and then twice daily for at least 5 weeks. Nine weeks after the last calving (at the end of the 3rd month of lactation, on average) each of the four groups (primiparous or multiparous cows $\times$ twice daily milking/day or three times milking/ 2 days in early lactation) that were being milked twice daily, was divided into two sub-groups: one continued to be milked twice daily whereas the other was milked three times/2 days for 3 weeks and then twice daily. All cows were fed ad libitum the same complete diet based on grass silage. In early lactation, milking three times $/ 2$ days decreased the milk yield $(3.4 \mathrm{~kg} / \mathrm{day} ; 16 \%)$, increased the fat $(5.0 \mathrm{~g} / \mathrm{kg})$ and protein $(2.2 \mathrm{~g} / \mathrm{kg})$ contents and decreased the lactose content $(1.5 \mathrm{~g} / \mathrm{kg})$ in primiparous cows. In multiparous cows, the milk changes $(-0.7 \mathrm{~kg},+0.9 \mathrm{~g}$ fat $/ \mathrm{kg},+0.6 \mathrm{~g}$ proteins $/ \mathrm{kg})$ were not significant. The energy balance was not changed. During the declining phase of lactation, milking three times $/ 2$ days reduced secretion of milk, fat, proteins and lactose by about $10 \%$ in both categories of cows. The milk composition remained unchanged. Food intake was not affected but the energy balance was improved.
\end{abstract}

dairy cow / milk production / milking frequency / stage of lactation / lactation rank

Résumé - Effet de la traite 3 fois en 2 j pendant les 3 premières semaines de la lactation ou pendant la phase descendante, sur la production laitière de vaches primipares ou multipares. Cinquante-deux vaches Holstein (26 primipares) ont été réparties au vêlage entre deux fréquences de traite : soit deux fois/jour ( 6 et $17 \mathrm{~h}$; témoin), soit trois fois $/ 2 \mathrm{j}(6,20$ et $14 \mathrm{~h}$ le jour suivant) pendant les 3 premières semaines de la lactation, puis deux fois/jour pendant au moins 5 semaines. Neuf semaines après le dernier vêlage (à la fin du $3^{\mathrm{e}}$ mois de lactation, en moyenne), chacun des quatre lots

\footnotetext{
* Correspondence and reprints: present address: École Nationale d'Ingénieurs des Travaux
} Agricoles, Marmilhat, 63370 Lempdes, France

Tel: 0473981313 ; fax: 0473981300 
(vaches primipares ou multipares $\times$ traite deux fois/jour ou trois fois $/ 2 \mathrm{j}$ en début de lactation), qui était alors trait deux fois/jour, a été subdivisé en deux sous-lots : l'un a continué à être trait deux fois/jour alors que l'autre a été trait trois fois $/ 2 \mathrm{j}$ pendant 3 semaines, puis de nouveau deux fois par jour. Tous les animaux ont été alimentés à volonté avec la même ration complète à base d'ensilage d'herbe. La traite trois fois $/ 2 \mathrm{j}$ en début de lactation a, chez les primipares, diminué la quantité de lait sécrétée de $3,4 \mathrm{~kg} / \mathrm{jour}(16 \%)$, augmenté les teneurs du lait en matières grasses $(5,0 \mathrm{~g} / \mathrm{kg})$ et en protéines $(2,2 \mathrm{~g} / \mathrm{kg})$, et diminué la teneur en lactose $(1,5 \mathrm{~g} / \mathrm{kg})$. Chez les multipares, les modifications de sécrétion laitière $(-0,7 \mathrm{~kg}$ lait, $+0,9 \mathrm{~g}$ matières grasses et $+0,6 \mathrm{~g}$ de protéines $/ \mathrm{kg}) \mathrm{n}$ 'ont pas été significatives. Le bilan énergétique n'a pas été modifié. Pendant la phase descendante de la lactation (début du $4^{e}$ mois de lactation en moyenne), la traite trois fois $/ 2 \mathrm{j}$ a réduit les quantités de lait, de matières grasses, de protéines et de lactose d'environ $10 \%$ chez les deux catégories de vaches. La composition du lait n'a pas changé pendant cette période. Les quantités d'aliments ingérées n'ont pas été affectées mais le bilan énergétique a été plus positif.

fréquence de traite / vache laitière / production laitière / stade de lactation / rang de lactation

\section{INTRODUCTION}

The main issues (feeding, health, reproduction, social environment) in dairy herd management are concentrated in the peripartum period and the 2 following months. They are largely the result of the nutritional deficit experienced by the cows during this period, which is due to their incapacity to increase their nutrient intake as rapidly as their milk secretion. The relative failure of nutrition in alleviating the metabolic load in early lactation and the milk quota policy (which determines the quantity of milk each farmer may sell, and which decreases the interest in maximizing the milk secretion of the cows) make it possible to try to adjust the milk secretion to the nutrient intake. This strategy, which is opposite to that implemented so far, could be achieved through a temporary lower milking frequency in early lactation.

Effect of milking frequency (ie, interval between milkings) on milk secretion rate has been studied for a long time. In analytical studies of short duration where the effects of previous milking intervals and residual milk were eliminated, physiologists have shown that milk secretion rate decreases curvilinearly with the duration of the milking interval (Wheelock et al, 1966) or is virtually constant over the first $16 \mathrm{~h}$ after milking (cf Elliott, 1959; Labussière and Richard, 1965), which would correspond to about $13 \mathrm{~h}$ under conventional milking conditions (Elliott et al, 1960). Loss in milk yield resulting from milking omissions depends on the characteristics of these omissions: frequency (from $35 \%$ and $50 \%$ for 1 omission/day (Claesson et al, 1959; Holmes et al, 1992) to only slightly for 1 omission/week (Labussière et Coindet, 1968; Radcliffe et al, 1973)), stage of lactation at which omissions are imposed (Eldridge and Clark, 1978), and duration of implementation (Claesson et al, 1959). Milk loss also depends on the cows' characteristics (rank of lactation (Woolford et al, 1985), breed (Carruthers et al, 1993), anatomy of the udder (Knight and Dewhurst, 1994)).

In a previous experiment (Rémond et al, 1992), milking primiparous cows three times/ 2 days in the first three weeks of lactation resulted in a large reduction in the loss of live weight $(-34 \mathrm{~kg} \mathrm{vs}-67 \mathrm{~kg})$ despite a moderate decrease (12\%) in milk yield. Moreover, the cows did not recover the control level of milk secretion once the twice daily milking frequency was resumed. To complete this experiment done with a few (12 in total) primiparous cows, we studied the three milkings/2 days again with a larger number of primiparous and multiparous cows and at two different lactation stages. 


\section{MATERIALS AND METHODS}

\section{Animals and experimental design}

Twenty-six primiparous lactating cows ( 31 months old at calving) and 26 multiparous cows ( 11 in 2nd lactation), of the Holstein-Friesian breed, were assigned at calving to two milking frequency regimes: a control frequency (two times/day at $6 \mathbf{h}$ and $17 \mathrm{~h}$ ) or a reduced frequency (three times $/ 2$ days at $6 \mathrm{~h}, 20 \mathrm{~h}$ and $14 \mathrm{~h}$ of the following day) for the first 3 weeks of lactation (experimental period 1) and then the control frequency. Nine weeks after the last cow had calved (after 13.3 weeks of lactation on average for all cows), each of these four groups (control or reduced milking frequency regime $\times$ primiparous or multiparous cows), which were then being milked twice daily, was divided at the same time into two similar sub-groups. One of the groups continued to be milked twice daily whereas the other was milked three times/2 days for 3 weeks (experimental period 2, from 5 to 25 February 1996), and then twice daily for at least 6 weeks. For both assignments of cows to experimental groups, the expected calving date, age, milk yield and composition (expected from the performance in the preceding lactation (multiparous cows) or from genetic index (primiparous cows), for period 1) and live weight were taken into account. The cows calved between 28 September and 6 December 1995.

\section{Husbandry}

Cows grazed in the pasture during the summer preceding calving. They were brought into the barn 3 weeks at least before their expected calving date or on 10 November. They were then housed together in a free-stall barn equipped with electronic gates. During the dry period indoors, they were fed grass silage ad libitum and an increasing quantity of concentrate $(1,2,3 \mathrm{~kg}$ during the last 3 weeks before calving). From their calving date to 25 February, all cows received once a day, ad libitum, at about $9 \mathrm{~h}$, a complete diet composed, on a dry matter basis, of $54 \%$ grass silage, $13 \%$ hay and $33 \%$ concentrate $(0.88$ feed unit for milk, $180 \mathrm{~g}$ crude protein, per $\mathrm{kg}$ dry matter). From 26 February (ie, from the week 1 of post-experimental period 2) onwards, maize silage was included in the complete diet which was then composed (DM basis) of $46 \%$ grass silage, $17 \%$ maize silage, $12 \%$ hay and
$25 \%$ concentrate $(0.85$ feed unit and $165 \mathrm{~g}$ crude protein per kg dry matter). The cows were milked in a milking parlour equipped with automatic cluster removers.

\section{Measurements and analyses}

Milk was weighed at each milking and sampled at each milking over 2 consecutive days for its fat, protein and lactose contents, and somatic cell count (infra-red spectrophotometry and automatic counting, respectively). In samples taken at the morning milking at weeks 3 and 12.3 (on average) of lactation, the soluble proteins (after clotting of caseins with rennet), serum albumin (radioimmunoassay technique; Levieux, 1991) and free fatty acids (Chazal and Chilliard, 1986) were also analysed. Food intake was measured 4 days weekly and live weight in the week after calving and then every other week. Blood was sampled from the caudal vein, between $8.30 \mathrm{~h}$ and $9.00 \mathrm{~h}$ (before diet distribution), in the $3 \mathrm{rd}$ week of lactation (last week of experimental period 1) for glucose, non-esterified fatty acids and 3-hydroxybutyrate analysis (enzymatic determination).

\section{Data analysis}

Data were subjected to variance-covariance analysis (GLM procedure, SAS, 1987). Variates included were milking frequency, lactation rank, and their interaction. Parameters of milk production (yield, composition) recorded in period 1 were subjected to two analyses: without covariate (data not presented) or with the data recorded in weeks 7 and 8 of lactation (weeks 4 and 5 of the post-experimental period) as a covariate. Three cows were dropped from the trial or the data analyses.

\section{RESULTS}

\section{Milk yield}

In experimental period 1, low milking frequency resulted in a reduction in milk yield that was higher in primiparous cows than in multiparous (fig 1 and table I). The depressive effect increased with the num- 

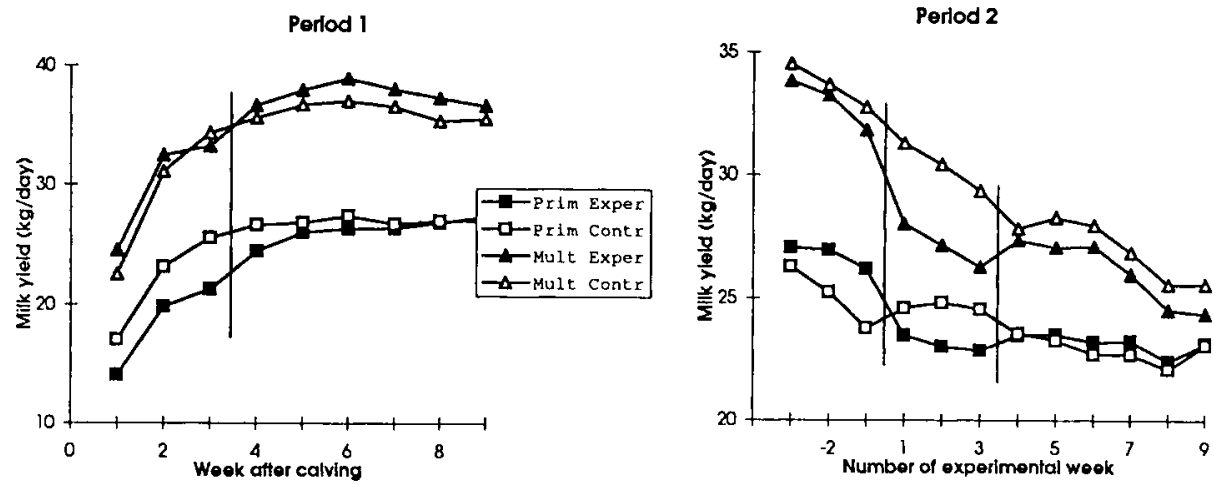

Fig 1. Effect of three milkings/2 days, compared to two milkings/day, applied for 3 weeks (1 to 3 ) in early lactation (period 1) or in the declining phase (period 2) on the milk yield by primiparous or multiparous cows.

Table I. Effect of three milkings/2 days compared to two milkings/day on milk yield and composition (adjusted means).

\begin{tabular}{|c|c|c|c|c|c|c|c|}
\hline \multirow{2}{*}{$\begin{array}{l}\text { Lactation rank } \\
\text { Milking frequency }\end{array}$} & \multicolumn{2}{|c|}{ Primiparous cows } & \multicolumn{2}{|c|}{ Multiparous cows } & \multicolumn{2}{|c|}{$\begin{array}{c}\text { Statistical effects } \\
\text { of }(P<)\end{array}$} & \multirow{2}{*}{$\begin{array}{c}\text { Residual } \\
\text { SD }\end{array}$} \\
\hline & $3 / 2$ days & $2 / d a y$ & $3 / 2$ days & $2 / d a y$ & Milk freq & Freq $\times$ rank & \\
\hline \multicolumn{8}{|l|}{ Period 1} \\
\hline Milk $(\mathrm{kg} / \mathrm{d})$ & $18.5 \mathrm{~A}$ & $21.9 \mathrm{~B}$ & $29.3 \mathrm{C}$ & $30.0 \mathrm{C}$ & 0.01 & 0.10 & 2.5 \\
\hline Fat $(\mathrm{g} / \mathrm{kg})$ & $47.1 \mathrm{ab}$ & $42.1 \mathrm{c}$ & $45.8 \mathrm{ad}$ & $44.9 \mathrm{ac}$ & 0.05 & NS & 4.9 \\
\hline Proteins $(\mathrm{g} / \mathrm{kg}$ ) & $35.3 \mathrm{a}$ & $33.1 \mathrm{~b}$ & $36.2 \mathrm{a}$ & $35.6 \mathrm{a}$ & NS & NS & 3.0 \\
\hline Lactose $(\mathrm{g} / \mathrm{kg})$ & $45.9 \mathrm{~A}$ & $47.4 \mathrm{~B}$ & $45.2 \mathrm{~A}$ & $46.2 \mathrm{~A}$ & 0.01 & NS & 1.5 \\
\hline $\begin{array}{l}\text { Somatic cells } \\
(\times 1000 / \mathrm{mL})^{1}\end{array}$ & 290 & 395 & 74 & 63 & NS & NS & \\
\hline Fat (g/day) & $878 \mathrm{~A}$ & $938 \mathrm{~A}$ & $1329 \mathrm{~B}$ & $1335 \mathrm{~B}$ & NS & NS & 144 \\
\hline Proteins (g/day) & $642 \mathrm{~A}$ & $721 \mathrm{~A}$ & $1048 \mathrm{~B}$ & $1053 \mathrm{~B}$ & NS & NS & 127 \\
\hline Lactose (g/day) & $863 \mathrm{~A}$ & $1060 \mathrm{~B}$ & $1350 \mathrm{C}$ & $1393 \mathrm{C}$ & 0.01 & 0.05 & 114 \\
\hline \multicolumn{8}{|l|}{ Period 2} \\
\hline Milk (kg/day) & $22.6 \mathrm{~A}$ & $25.1 \mathrm{~B}$ & $27.4 \mathrm{C}$ & $30.1 \mathrm{D}$ & 0.01 & NS & 2.0 \\
\hline Fat $(\mathrm{g} / \mathrm{kg})$ & $39.7 \mathrm{a}$ & $39.9 \mathrm{ab}$ & $41.0 \mathrm{ab}$ & $41.5 b$ & NS & NS & 2.4 \\
\hline Proteins $(\mathrm{g} / \mathrm{kg})$ & $32.8 \mathrm{a}$ & $32.6 \mathrm{ab}$ & $32.2 \mathrm{~b}$ & $32.2 \mathrm{ab}$ & NS & NS & 0.9 \\
\hline Lactose $(\mathrm{g} / \mathrm{kg})$ & $50.0 \mathrm{~A}$ & $50.3 \mathrm{~A}$ & $47.8 \mathrm{~B}$ & $48.3 \mathrm{~B}$ & NS & NS & 1.0 \\
\hline Fat (g/day) & $898 \mathrm{~A}$ & $1000 \mathrm{~B}$ & $1123 \mathrm{C}$ & $1233 \mathrm{D}$ & 0.01 & NS & 87 \\
\hline Proteins (g/day) & $734 \mathrm{~A}$ & $813 \mathrm{~B}$ & $878 \mathrm{C}$ & $961 \mathrm{D}$ & 0.01 & NS & 64 \\
\hline Lactose (g/day) & $1130 \mathrm{~A}$ & $1265 \mathrm{~B}$ & $1315 \mathrm{~B}$ & $1454 \mathrm{C}$ & 0.01 & NS & 111 \\
\hline
\end{tabular}

Means with different capital letters are different at 0.01 or 0.05 level of significance; means with different lower case letters are different at 0.10 level; NS, not significant. 'Data calculated on logarithms of the number of cells. 
ber of the weeks the cows experienced the reduced milking frequency (RMF), being significant for each of the 3 weeks in primiparous cows $(-2.8 \mathrm{~kg} /$ day,$P<0.1$; $-3.1 \mathrm{~kg} / \mathrm{day}, P<0.01$; $-4.1 \mathrm{~kg} / \mathrm{day}$, $P<0.01$, for weeks 1,2 and 3 , respectively) but only for week 3 in multiparous cows (+ $0.7 \mathrm{~kg} /$ day, $P>0.1 ; 0 \mathrm{~kg} /$ day,$P>0.1$; $-2.7 \mathrm{~kg} /$ day,$P<0.1$, respectively). Consequently, the average milk yield over the 3 weeks of RMF only decreased in primiparous cows. During period 2, the depressive effect was similar for both categories of cows $(\sim 10 \%)$ and for the 3 experimental weeks. In both post-experimental periods, differences in milk yield and composition between control cows and cows milked less frequently ceased to be significant (when they were) after 1 or 2 weeks of twice daily milking regime.

Decreases in milk yield due to RMF (as observed by the milk yield augmentation between week 3 and 4 for period 1 and by the milk yield decrease between pre-experimental weeks $-1+-2$ (mean) and experimental week 3 for period 2) were not related to the milk yield of the cows $(P=0.739$ and $P=0.622$, respectively). For the 11 cows that were milked three times/ 2 days during both experimental periods, the relationship between both milk yield decreases (same definitions as earlier) was not significant.

\section{Milk composition}

During period 1, RMF significantly decreased the lactose content $(\mathrm{g} / \mathrm{kg})$, increased the fat and protein content and did not change somatic cell number, in primiparous cows (table I). No significant change in milk composition was observed in multiparous cows. Consequently, RMF only decreased lactose secretion ( $\mathrm{g} /$ day) in primiparous cows. During period 2, the lactose, fat and protein contents remained unchanged in both categories of cows. Secretions of milk, lactose, fat and proteins decreased by about $10 \%$ in both categories of cows.

At week 3 of lactation, RMF significantly increased the soluble protein content, in primiparous cows (table II). Because the content in renneted proteins was not significantly affected, the casein/protein ratio decreased. The serum albumin content tended $(P<0.10)$ to increase in multiparous cows submitted to RMF. These parameters did not change between milking frequencies in the post-experimental period (week 12.3 on average).

\section{Nutritional indices}

RMF did not significantly change food intake during either experimental period, but improved the energy balance during period 2 (significant effect for multiparous cows). Live weights in week 1 of lactation were $596 \mathrm{~kg}$ for primiparous cows and $662 \mathrm{~kg}$ for multiparous. They slightly decreased during period 1 ( $12 \mathrm{~kg}$ for primiparous cows between calving and week 3 of lactation, $13 \mathrm{~kg}$ for multiparous cows between calving and week 8 of lactation), but were not different between both milking frequency regimes. During period 2, liveweight augmentations were not significantly different.

Plasma concentrations (measured during week 3 of lactation) in glucose, non-esterified fatty acids and 3-hydroxybutyrate were not modified by RMF in primiparous cows (0.64 g/L, $0.29 \mathrm{mmol} / \mathrm{L}$; $0.85 \mathrm{mmol} / \mathrm{L}$ respectively, on average for both milking frequency regimes). In multiparous cows, RMF tended to decrease the glucose concentration $(0.53$ vs $0.58 \mathrm{~g} / \mathrm{L} ; P=0.101)$ and increased the 3 -hydroxybutyrate ( $1.74 \mathrm{mmol} / \mathrm{L}$ vs $1.00 \mathrm{mmol} / \mathrm{L} ; P<0.01$ ) concentration. The concentration in nonesterified fatty acids was unaffected. 
Table II. Effect of three milkings/2days compared to two milkings/day on the concentration of some protein fractions and of the free fatty acids in the milk secreted during the experimental period 1 (week 3 of lactation) and during the post-experimental period 1 (week 12.3 of lactation, on average).

\begin{tabular}{|c|c|c|c|c|c|c|}
\hline \multirow[b]{2}{*}{ Milking frequency } & \multicolumn{2}{|c|}{ Primiparous cows } & \multicolumn{2}{|c|}{ Multiparous cows } & \multirow{2}{*}{$\begin{array}{c}\text { Statistical } \\
\text { effects of } \\
\text { Milk freq }^{2}\end{array}$} & \multirow{2}{*}{$\begin{array}{c}\text { Residual } \\
\text { SD }\end{array}$} \\
\hline & 3/2 days & $2 / d a y$ & $3 / 2$ days & $2 / d a y$ & & \\
\hline \multicolumn{7}{|l|}{ Experimental period $*$} \\
\hline Renneted proteins $(\mathrm{g} / \mathrm{kg})$ & 26.3 & 25.9 & 26.7 & 26.4 & NS & 2.1 \\
\hline Soluble proteins $(\mathrm{g} / \mathrm{kg}$ ) & $6.1 \mathrm{a}$ & $5.3 \mathrm{~b}$ & $5.4 \mathrm{~b}$ & $5.3 b$ & 0.05 & 1.0 \\
\hline $\begin{array}{l}\text { Renneted proteins } \\
\text { (\% total proteins) }\end{array}$ & $81.3 \mathrm{~A}$ & $83.1 \mathrm{~B}$ & $83.3 \mathrm{~B}$ & $83.3 \mathrm{~B}$ & 0.05 & 2.2 \\
\hline Serum albumin $(\mathrm{mg} / \mathrm{L})$ & $138 \mathrm{ab}$ & $133 \mathrm{ab}$ & $150 \mathrm{a}$ & $116 b$ & NS & 41 \\
\hline $\begin{array}{l}\text { Free fatty acids } \\
\text { (mg C16/100 g fat) }\end{array}$ & 139 & 133 & 107 & 151 & NS & 72 \\
\hline \multicolumn{7}{|l|}{ Post-experimental period ${ }^{1}$} \\
\hline Renneted proteins $(\mathrm{g} / \mathrm{kg})$ & 26.5 & 27.6 & 26.5 & 26.9 & NS & 1.9 \\
\hline Soluble proteins $(\mathrm{g} / \mathrm{kg}$ ) & 5.5 & 5.7 & 5.3 & 5.5 & NS & 0.9 \\
\hline $\begin{array}{l}\text { Renneted proteins } \\
\text { (\% total proteins) }\end{array}$ & 82.8 & 82.8 & 83.5 & 83.0 & NS & 2.1 \\
\hline Serum albumin $(\mathrm{mg} / \mathrm{L})$ & 152 & 148 & 162 & 135 & NS & 40 \\
\hline $\begin{array}{l}\text { Free fatty acids } \\
\text { (mg C16/100 g fat) }\end{array}$ & $145 \mathrm{ab}$ & $146 \mathrm{~b}$ & $176 \mathrm{c}$ & $160 \mathrm{abc}$ & NS & 41 \\
\hline
\end{tabular}

\footnotetext{
I Adjusted means calculated with the variates: lactation rank, milking frequency, their interaction and, for period 1 , data recorded in the post-experimental period.

${ }^{2}$ Interaction "lactation rank (primiparous or multiparous cows) $\times$ milking frequency" was never significant. Means with different capital letters are different at 0.01 or 0.05 level of significance; means with different lower case letters are different at 0.10 level; NS, not significant.
}

\section{DISCUSSION}

\section{Statistical analysis}

The effects of RMF during period 1 that are presented are those provided by statistical analyses done with data recorded at the end of post-experimental period as a covariate. These analyses are not statistically "correct" since they imply that the effects of RMF, when present, have entirely disappeared at the end of the post-experimental period. Nevertheless this decision seems well grounded for several reasons: i) differences between treatments, when present, were observed to fade rapidly once control milking frequency was implemented (see figure 1 for milk yield); ii) statistical analyses without covariate provided weekly evolutions of the effect of RMF similar to those provided by analyses with covariate, but sometimes different estimated effects, probably because they did not take into account intrinsic differences between groups of cows. For instance, experimental multiparous cows produced $1.8 \mathrm{~kg}$ milk more than controls in late post-experimental period, which is likely due to their higher 
Table III. Effect of three milkings/2 days compared to two milkings/day on feed intake, live weight and energy balance (adjusted means).

\begin{tabular}{|c|c|c|c|c|c|c|c|}
\hline \multirow{2}{*}{$\begin{array}{l}\text { Lactation rank } \\
\text { Milking frequency }\end{array}$} & \multicolumn{2}{|c|}{ Primiparous cows } & \multicolumn{2}{|c|}{ Multiparous cows } & \multicolumn{2}{|c|}{$\begin{array}{c}\text { Statistical effects } \\
\text { of }(P<)\end{array}$} & \multirow{2}{*}{$\begin{array}{l}\text { Residual } \\
\text { SD }\end{array}$} \\
\hline & $3 / 2$ days & $2 / d a y$ & $3 / 2$ days & $2 / d a y$ & Milk freq & Freq $\times$ rank & \\
\hline \multicolumn{8}{|l|}{ Period I } \\
\hline $\begin{array}{l}\text { Dry matter intake } \\
(\mathrm{kg} / \text { day })^{1}\end{array}$ & $13.9 \mathrm{~A}$ & $13.2 \mathrm{~A}$ & $16.9 \mathrm{~B}$ & $17.6 \mathrm{~B}$ & NS & NS & 1.9 \\
\hline Live weight $(\mathrm{kg})^{2}$ & $587 \mathrm{~A}$ & $588 \mathrm{~A}$ & $656 \mathrm{~B}$ & $660 \mathrm{~B}$ & NS & NS & 23 \\
\hline $\begin{array}{l}\text { Energy balance } \\
\text { (FU/day })^{1}\end{array}$ & $-1.7 \mathrm{~A}$ & $-2.9 \mathrm{AC}$ & $-4.4 \mathrm{~B}$ & $-3.7 \mathrm{BC}$ & NS & 0.10 & 1.9 \\
\hline \multicolumn{8}{|l|}{ Period 2} \\
\hline $\begin{array}{l}\text { Dry matter intake } \\
(\mathrm{kg} / \text { day })^{1}\end{array}$ & $20.4 \mathrm{~A}$ & $21.1 \mathrm{~A}$ & $23.7 \mathrm{~B}$ & $23.4 \mathrm{~B}$ & NS & 0.05 & 0.9 \\
\hline $\begin{array}{l}\text { Live weight } \\
(\mathrm{kg})^{3}\end{array}$ & $625 \mathrm{~A}$ & $630 \mathrm{~A}$ & $669 \mathrm{~B}$ & $670 \mathrm{~B}$ & NS & NS & 15 \\
\hline $\begin{array}{l}\text { Energy balance } \\
(\mathrm{FU} / \text { day })^{1}\end{array}$ & $3.1 \mathrm{AB}$ & $2.3 \mathrm{BC}$ & $3.2 \mathrm{~A}$ & $2.0 \mathrm{C}$ & 0.01 & NS & 1.0 \\
\hline
\end{tabular}

Means with different capital letters are different at 0.01 or 0.05 level of significance; NS, not significant.

${ }^{1}$ Means for the three experimental weeks. ${ }^{2}$ Live weight in week 4 calculated with live weight at week 1 as a covariate. ${ }^{3}$ Live weight at week 1 of the post-experimental period, calculated with the live weight in the preexperimental period 2 as a covariate.

capacity for milk secretion, despite the fact that the assignment of multiparous cows to experimental groups for period 1 was based on milk yield in the previous lactation (see Materials and methods); and iii) a more severe restriction of milking frequency than was used in this trial (1/day) had no carryover effect on milk yield (Knight and Dewhurst, 1994) or an apparently low effect (Stelwagen et al, 1994). Recovery of control milk composition is even more rapid than that of milk yield (Wheelock et al, 1965) once control milking frequency was resumed.

\section{Performance}

The very low effects of an omission rate of one milking/ 2 days in multiparous cows in early lactation are consistent with the data of Eldridge and Clark (1978), which showed an effect of milking omission that is all the more lower as it is implemented sooner in the lactation. High levels of growth hormone $(\mathrm{GH})$ secretion during this period (Bines and Hart, 1982) could maintain high levels of milk secretion despite the lengthening milking interval. Stelwagen et al (1994) showed that the milk yield increase resulting from the administration of exogenous $\mathrm{GH}$ in late lactation can offset more than the loss of milk resulting from the change from twice-daily to once-daily milking. Nevertheless, in primiparous cows, milk yield loss was relatively high (16\%) and of the same order as that observed in a previous trial (-12\%; Rémond et al, 1992). This particular sensitivity of the udder of primiparous cows might be related to their incom- 
plete development in early lactation, contrary to multiparous cows, as shown in goats (Knight and Wilde, 1993). Moreover, possible effects due to the fact that primiparous cows are not habituated to milking cannot be discarded.

During the declining phase of lactation, losses in milk yield resulting from milking three times/2 days were moderate and similar for both primiparous $(-10 \%)$ and multiparous $(-9 \%)$ cows, in contrast with our observations for early lactation and with the data recorded by Woolford et al (1985) over an entire lactation ( $-18 \%$ for primiparous cows; $-7 \%$ for multiparous). Little data are available that compare the udder capacity of primiparous and multiparous cows. Dewhurst and Knight (1994) showed that cistern milk as a proportion of total milk yield tended to be lower for primiparous than for multiparous cows, which would be consistent with the higher sensitivity of primiparous cows to milking omissions. Nevertheless, Davis and Hughson (1988) have shown that the functional capacity of the udder (liters of milk contained in the udder after $49 \mathrm{~h}$ without milking/previous hourly rate of milk secretion in a twice-daily milking regime, expressed in hours) is not different $(P>0.10)$ between primiparous cows $(27 \mathrm{~h})$ and multiparous (33 h). Moreover, Walsh (1976) observed that omission of the first four or eight consecutive milkings after calving has a larger deleterious effect on milk yield in multiparous cows than in primiparous.

A lack of RMF carry-over effect in the declining phase of lactation, once the control milking frequency regime was resumed, was expected (see above). It was more surprising in early lactation, mostly in primiparous cows whose udder continues its development during this period (cf, Knight and Wilde, 1993). Knight and Dewhurst (1994) wondered if the lack of carry-over effect in mid-lactation in their trial should also have been observed in early lactation. In a pre- vious trial involving 12 primiparous cows we did not observe milk yield recovery once twice daily milking was applied (Rémond et al, 1992). In the present trial, despite milk yield reduction (in primiparous cows), RMF did not reduce the long-term milk secretion capacity of the udder which suggested that neither the number of secretory cells nor their potential activity were affected. During this period, cows display a particular hormonal pattern in their blood, which has an high GH content. This may make it possible to preserve the normal development of secretory parenchyma despite the reduction (moderate and of relatively short duration in our trial) in milking frequency, as suggested by Knight and Wilde (1993). The lack of notable change of serum albumin concentration in the milk (an index of the tight junction integrity of secretory epithelium; Stelwagen et al, 1994) agrees with the observation of an increase in the amount of this protein for milking intervals higher than $18 \mathrm{~h}$ (Stelwagen et al, 1995). The decrease in milk yield due to RMF, then seemed attributable to local regulation by a protein secreted in milk (feedback inhibitor of lactation; Wilde et al, 1995) rather than to a disruption of secretory cell tight junctions as suggested by Stelwagen et al (1994).

The changes in milk composition recorded in primiparous cows during period 1 agreed with those commonly observed with RMF (Claesson et al, 1959; Holmes et al, 1992; Carruthers et al, 1993). The increase in soluble proteins, only observed in primiparous cows during period 1, was already recorded by Claesson et al (1959). Surprisingly, it was in multiparous cows that the serum albumin content tended to increase.

During period 1, the lower energy balance (not significant) in multiparous cows milked less frequently was consistent with the increase of plasma 3-hydroxybutyrate. It was probably due to their slightly effective higher milk yield $(1.3 \mathrm{~kg}$ fat-corrected 
milk/day) and their slightly lower food intake $(0.7 \mathrm{~kg}$ dry matter/day). We previously observed a reduction of $33 \mathrm{~kg}$ in the live weight loss of primiparous cows milked three times/2 days in early lactation (Rémond et al, 1992). The fact that the nutritive requirements were met more satisfactorily in the present trial (low decrease in live-weight) was perhaps a reason for the discrepancy between our two trials. During period 2, the lack of effect of RMF on food intake, and the depressive effect on milk yield improved the overall energy balance. With RMF, Claesson et al (1959), Woolford et al (1985) and Holmes et al (1992) recorded higher live-weight gains during the declining phase of lactation.

In conclusion, omission of one milking/2 days accompanied by a rearrangement of milking hours resulting in approximately similar milking intervals did not result in a decrease in milk yield that was high and rapid enough to improve the nutritional balance of cows in early lactation. A more severe reduction of milking frequency will have to be tested.

\section{ACKNOWLEDGMENTS}

We gratefully acknowledge JC Bonnefoy and D Levieux for the laboratory analyses, and C Péry, $M$ Barbet and their colleagues from the experimental farm of Orcival (INRA) for managing the trial and taking care of the cows.

\section{REFERENCES}

Bines JA, Hart IC (1982) Metabolic limits to milk production, especially roles of growh hormone and insulin. J Dairy Sci 65, 1375-1389

Carruthers VC, Davis SR, Bryant AM, Henderson HV, Morris CA, Copeman PJA (1993) Response of Jersey and Friesian cows to once a day milking and prediction of response based on udder characteristics and milk composition. J Dairy Res 60, 1-11

Chazal MP, Chilliard Y (1986) Effect of stage of lactation, stage of pregnancy, milk yield and herd management on seasonal variation in spontaneous lipolysis in bovine milk. J Dairy Res 53, 529-538
Claesson O, Hansson A, Gustafsson N, Brännäng E (1959) Studies on monozygous cattle twins. 17. Once-a-day milking compared with twice-a-day milking. Acta Agric Scand 9, 38-58

Davis SR, Hugson GA (1988) Measurement of functional udder capacity in lactating Jersey cows. Aust J Agric Res 39, 1163-1168

Dewhurst RJ, Knight CH (1994) Relationship between characteristics and the short-term response of dairy cows to thrice-daily milking. Anim Prod 58, $181-187$

Eldridge GA, Clark J (1978) Production of cows milked 3 times each 2 days. $J$ Dairy Res $45,509-513$

Elliott GM (1959) The direct effect of milk accumulation in the udder of the dairy cow upon milk secretion rate. Dairy Sci Abstr 21, 435-439

Elliott GM, Dodd FH, Brumby PJ (1960) Variations in the rate of milk secretion in milking intervals of 2 24 hours. J Dairy Res 27, 293-308

Holmes CW, Wilson GF, Mackenzie DDS, Purchas J (1992) The effects of milking once daily throughout lactation on the performance of dairy cows grazing on pasture. Proc NZAnim Prod 52, 13-16

Knight CH, Wilde CJ (1993) Mammary cell changes during pregnancy and lactation. Livest Prod Sci 35 , 3-19

Knight CH, Dewhurst RJ (1994) Once daily milking of dairy cows: relationship between yield loss and cisternal milk storage. J Dairy Res 61, 441-449

Labussière J, Richard P (1965) La traite mécanique. Aspects anatomiques, physiologiques et technologiques. Mise au point bibliographique. Ann Zootech 14, 63-126

Labussière J, Coindet J (1968) Effets de la suppression de la traite du dimanche soir, chez les bovins de race française frisonne pie noire. Ann Zootech 17 , 231-244

Levieux D (1991) Dosage des IgG du lait par immunodiffusion radiale semi-automatisée, pour la détection du colostrum, des laits de mammites ou de fin de gestation - I - Mise au point du dosage. Lait 71 , $327-338$

Radcliffe JC, Bailey LF, Horne ML (1973) Periodic omission of dairy cow milkings - I - Effect on milk yield and composition and on udder health. $J$ Dairy Res 40, 247-254

Rémond B, Petit M, Ollier A (1992) Milking primiparous cows three times every two days in early lactation: milk secretion and nutritional status. In: Prospects for automatic milking, (Ipema AH, Lippus AC, Metz JHM, Rossing W, eds), Pudoc Scientific Publishers, Wageningen, EAAP Publication $n^{\circ} 65,227-232$

Statistical Analysis Systems Institute (1987) SAS User'Guide: Statistics. SAS Institute, Inc. Cary, North Carolina, USA

Stelwagen K, Davis SR, Farr VC, Eichter SJ, Politis I (1994) Effect of once daily milking and concur- 
rent somatotropin on mammary tight junction permeability and yield of cows. I Dairy Sci 77 , 2994-3001

Stelwagen K, Farr VC, Davis SR (1995) Timing of once daily milking induced disruption of bovine mammary tight junctions during early lactation. $J$ Dairy Sci 78 (suppl 1), 204 (abstr)

Walsh JP (1976) Bovine milk secretion following the omission of milkings immediatly postpartum and during mid-lactation. Ir J Agric Res 15, 91-106

Wheelock JV, Rook JAF, Dodd FH (1965) The effect of incomplete milking or of an extended milking interval on the yield and composition of cow's milk. J Dairy Res, 32, 237-248

Wheelock JV, Rook JAF, Dodd FH, Griffin TK (1966) The effect of varying the interval between milkings on milk secretion. J Dairy Res 33, 161-176

Wilde CJ, Addey CVP, Boddy LM, Peaker M (1995) Autocrine regulation of milk secretion by a protein in milk. Biochem $J 305,51-58$

Woolford MW, Copeman PJA, Napper AR, Phillips DSM, Williamson JH, Uljee EJ (1985) Milking intervals: are changes worthwhile? Proc Ruakura Farmers' Conf 37, 120-128 